\title{
$\beta$-Carotene inhibits inflammatory gene expression in lipopolysaccharide-stimulated macrophages by suppressing redox-based NF-kB activation
}

\author{
Se-Kyung Bai ${ }^{1,2}$, Seon-Jin Lee ${ }^{1}$, Hee-Jun $\mathrm{Na}^{1}$, \\ Kwon-Soo $\mathrm{Ha}^{1}$, Jeong-A Han ${ }^{1}$, Hansoo Lee ${ }^{1}$, \\ Young-Guen Kwon ${ }^{3}$, Cha-Kwon Chung ${ }^{2}$ \\ and Young-Myeong $\mathrm{Kim}^{1,4}$ \\ ${ }^{1}$ Vascular System Research Center \\ Department of Molecular and Cellular Biochemistry \\ School of Medicine, Kangwon National University \\ Chunchon, Kangwon-do 200-701, Korea \\ ${ }^{2}$ School of Life Sciences, Hallym University \\ Chunchon, Kangwon-do 200-702, Korea \\ ${ }^{3}$ Department of Biochemistry \\ College of Sciences, Yonsei University \\ Seoul 120-749, Korea \\ ${ }^{4}$ Corresponding author: Tel, 82-33-250-8831; \\ Fax, 82-244-3286; E-mail, ymkim@kangwon.ac.kr
}

Accepted 7 July 2005

Abbreviations: COX-2, cyclooxygenase-2; $\mathrm{DCFH}_{2}$-DA, 2',7'-dichlorofluorescin diacetate; DPI, diphenylene iodonium; IKK, IKB kinase; iNOS, inducible nitric oxide synthase; NF- $\kappa B$, nuclear factor-kappa $B$; NO, nitric oxide; NOx, nitrite plus nitrate; PDTC, pyrrolidine dithiocarbamate; RT-PCR, reverse transcriptase-PCR

\begin{abstract}
$\beta$-Carotene has shown antioxidant and antiinflammatory activities; however, its molecular mechanism has not been clearly defined. We examined in vitro and in vivo regulatory function of $\beta$-carotene on the production of nitric oxide (NO) and $\mathrm{PGE}_{2}$ as well as expression of inducible NO synthase (iNOS), cyclooxygenase-2, TNF- $\alpha$, and IL-1 $\beta$. $\beta$ Carotene inhibited the expression and production of these inflammatory mediators in both LPSstimulated RAW264.7 cells and primary macrophages in a dose-dependent fashion as well as in LPS-administrated mice. Furthermore, this com pound suppressed NF-KB activation and iNOS promoter activity in RAW264.7 cells stimulated with LPS. $\beta$-Carotene blocked nuclear translocation of NF- $\kappa B$ p65 subunit, which correlated with its inhibitory effect on $I \kappa B \alpha$ phosphorylation and
\end{abstract}

degradation. This compound directly blocked the intracellular accumulation of reactive oxygen species in RAW264.7 cells stimulated with LPS as both the NADPH oxidase inhibitor diphenylene iodonium and antioxidant pyrrolidine dithiocarbamate did. The inhibition of NADPH oxidase also inhibited NO production, iNOS expression, and iNOS promoter activity. These results suggest that $\beta$ carotene possesses anti-inflammatory activity by functioning as a potential inhibitor for redox-based NF- $\mathrm{KB}$ activation, probably due to its antioxidant activity.

Keywords: beta-carotene; cytokines; macrophages; nitric oxide; NF-KB; reactive oxygen species.

\section{Introduction}

Macrophages play an important role in host defense against noxious substances and are involved in a variety of disease processes, including autoimmune diseases, infections, and inflammatory disorders (Pierce, 1990). Inflammatory stimuli such as LPS and IFN- $\gamma$ activate macrophages to produce a variety of pro-inflammatory cytokines such as TNF- $\alpha$ and IL-1 $\beta$ as well as other inflammatory mediators including $\mathrm{PGE}_{2}$ and nitric oxide (NO), which are synthesized by cyclooxygenase (COX) and inducible nitric oxide synthase (iNOS), respectively. These inflammatory mediators are involved in the pathogenesis of many inflammation-associated human diseases (Simons et al., 1996; Guslandi, 1998; Ritchlin et al., 2003). Antiinflammatory drugs and agents reduce the inflammatory response by suppressing the production of the inflammatory mediators and in turn block the initiation and progression of inflammation-associated diseases (Leach et al., 1998; Ritchlin et al., 2003).

Expression of these cytokine and enzyme genes can be regulated by the activation of the transcription factor nuclear factor-kappa $B(N F-\kappa B)$, which is critically involved in several aspects of the pathogenesis of rheumatoid arthritis and other chronic inflammatory diseases (Makarov, 2000; Tak et al., 2001). NF- $K B$ is activated as a consequence of phosphorylation, ubiquitination, and subsequent proteolytic degradation of the $I \kappa B$ protein through activation of IKB kinase (IKK) (de Martin et al., 1993). The 
liberated NF- $\mathrm{KB}$ translocates into nuclei and binds to ( $B$ motifs in the promoters of pro-inflammatory genes such as iNOS, COX-2, TNF- $\alpha$, and IL-1 $\beta$, leading to the induction of their mRNA expression. Most of the anti-inflammatory drugs have been shown to suppress the expression of these genes by inhibiting the $N F-\kappa B$ activation pathway (Gilroy et al., 2004). Thus, an $N F-\kappa B$ inhibitor may be useful as a potential therapeutic drug in clinical applications for regulating the inflammation associated human diseases.

It has been also demonstrated that antioxidants such as $\alpha$-tocopheryl succinate (Neuzil et al., 2001), probucol (Dichtl et al., 1999), and astaxanthin (Lee et al., 2003a) can inhibit NF-KB activity and block the expression of pro-inflammatory genes as well as production of $\mathrm{NO}$ and $\mathrm{PGE}_{2}$ (Heiss et al., 2001), probably by the inhibition of NF- $\mathrm{KB}$ activation. These observations indicate that reactive oxygen species (ROS) plays an important role in NF- $\kappa B$ activation and inflammatory gene expression. $\beta$-carotene acts as a powerful antioxidant in oxidative stress and chain breaking antioxidant in lipid peroxidation (Smith, 1998) and prevents the development of inflammatory diseases such as atherosclerosis (Vivekananthan et al., 2003) and rheumatoid arthritis (Heliovaara et al., 1994).

We here hypothesized that $\beta$-carotene may inhibit the expression of pro-inflammatory gene expression and the production of inflammatory mediators such as $\mathrm{NO}$ and $\mathrm{PGE}_{2}$ through the inhibition of $\mathrm{NF}-\kappa \mathrm{B}$ activation. We found that $\beta$-carotene suppressed the expression of iNOS, TNF- $\alpha$, IL-1 $1 \beta$, and COX- 2 as well as the production of $\mathrm{NO}$ and $\mathrm{PGE}_{2}$ in LPS-stimulated macrophages and LPS-administrated mice. This compound also blocked iNOS promoter activity and NF$\kappa B$ activation and reduced the accumulation of intracellular ROS level in LPS-activated macrophages. Thus, these results indicate that $\beta$-carotene possesses anti-inflammatory potential by suppressing inflammatory cytokines and modulators through the suppression of redox-based NF- $\mathrm{KB}$ activation.

\section{Materials and Methods}

\section{Materials}

Dulbecco's modified Eagle's medium, penicillin, and streptomycin were purchased from Life Technology Inc. (Rockville, MD). LPS (Escherichia coli O111:B4) and $\beta$-carotene were obtained from Sigma (St. Louis, MO). Poly (dl-dC) and NF-кB-specific oligonucleotide were obtained from Promega (Madison, WI). Monoclonal iNOS antibody was purchased from Transduction Laboratories (Lexington, KY). Antibodies for

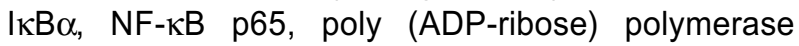
(PARP), COX-2, TNF- $\alpha$, and IL-1 $\beta$ were obtained from Santa Cruz Biotechnology (Santa Cruz, CA). 2',7'-dichlorofluorescin diacetate $\left(\mathrm{DCFH}_{2}-\mathrm{DA}\right)$ was purchased from Molecular probe (Eugene, OR). Other chemicals were obtained from Sigma (St. Louis, MO) unless indicated otherwise.

\section{Macrophage isolation and cell culture}

Murine macrophage cell line RAW264.7 was cultured in Dulbecco's modified Eagle's medium (2 mM L-glutamine; $100 \mathrm{U} / \mathrm{ml}$ penicillin; $100 \mu \mathrm{g} / \mathrm{ml}$ streptomycin) plus $10 \%$ fetal bovine serum (HyClone Labs, Logan, UT). Peritoneal macrophages were collected from the peritoneal cavity of 6-8 week old female BALB/c mice (Daihan-Biolink, Korea) given an intraperitoneal injection of $1.5 \mathrm{ml}$ of thioglycollate broth (4\%) 7 days before harvest. Cells were cultured in 6 -well plates $\left(3 \times 10^{6}\right.$ cells/well $)$ for $12 \mathrm{~h}$. Cells were stimulated with LPS $(1 \mu \mathrm{g} / \mathrm{ml})$ in the presence or absence of $\beta$-carotene.

\section{Animal treatment}

Mice (6 to 8 week old female BALB/c mice, DaihanBiolink, Korea) were intraperitoneally injected with LPS (4 mg/kg) and/or $\beta$-carotene (10 mg/kg). After 12 $\mathrm{h}$, whole blood samples were withdrawn by cardiac puncture. Serum was prepared by centrifugation at $12,000 \mathrm{~g}$ for $20 \mathrm{~min}$ at $4^{\circ} \mathrm{C}$ and kept at $-20^{\circ} \mathrm{C}$ until use.

Measurement of NO metabolites, cytokines, and $\mathrm{PGE}_{2}$ : nitrite, a stable oxidized product of $\mathrm{NO}$, was determined in cell culture medium by Griess reagents (Kim et al., 1997). Serum nitrite plus nitrate (NOx) concentration was determined by using a nitrate reductase-based colorimetric assay kit (Alexis San Diego, CA). $\mathrm{PGE}_{2}$ concentration was determined using an enzyme immunoassay kit (Amersham Pharmacia Biotech, Piscataway, NJ). The levels of TNF- $\alpha$ and $\mathrm{IL}-1 \beta$ in the culture medium and serum were determined using ELISA kits (R\&D Systems, Minneapolis, MN).

\section{Western blot analysis}

Cells were incubated with or without LPS in the absence or presence of $\beta$-carotene. Cells were harvested, washed twice with ice-cold phosphatebuffered saline (PBS), and resuspended in PBS containing $0.1 \mathrm{mM}$ phenylmethylsulfonyl fluoride. The suspension was lysed by three cycles of freezing and thawing. The cytosolic fractions were obtained from the supernatant after centrifugation at $12,000 \mathrm{~g}$ at $4^{\circ} \mathrm{C}$ for $20 \mathrm{~min}$. The protein content was determined by the BCA method (Pierce, Rockford, IL). Samples (40 $\mu \mathrm{g}$ of protein) were separated on SDS-PAGE and transferred onto nitrocellulose membranes. The mem- 
branes were blocked with $5 \%$ nonfat-dried milk in PBS containing $0.1 \%$ Tween 20 (PBST) for $2 \mathrm{~h}$, and then incubated with monoclonal mouse iNOS antibody in PBST containing 1\% nonfat milk for $2 \mathrm{~h}$. After washing three times with PBST, membrane was hybridized with horseradish peroxidase-conjugated secondary antibody for $1 \mathrm{~h}$. Following five washes, membranes were incubated with chemiluminescent solution for $2 \mathrm{~min}$, and the protein bands were visualized on X-ray film.

\section{Reverse transcriptase-polymerase chain reaction (RT-PCR) analysis}

Three $\mu \mathrm{g}$ of mRNA was converted to cDNA by treatment with $200 \mathrm{U}$ of reverse transcriptase and 500 $\mathrm{ng}$ of oligo-dT primer in $50 \mathrm{mM}$ Tris- $\mathrm{HCl}(\mathrm{pH}$ 8.3), 75 $\mathrm{mM} \mathrm{KCl}, 3 \mathrm{mM} \mathrm{MgCl}$, $10 \mathrm{mM}$ DTT, and $1 \mathrm{mM}$ dNTPs at $42^{\circ} \mathrm{C}$ for $1 \mathrm{~h}$. The reaction was stopped by heating at $70^{\circ} \mathrm{C}$ for $15 \mathrm{~min}$. Three $\mu \mathrm{l}$ of the cDNA mixture was used for enzymatic amplification. PCR was performed in $50 \mathrm{mM} \mathrm{KCl}, 10 \mathrm{mM}$ Tris- $\mathrm{HCl}(\mathrm{pH} \mathrm{8.3),} 1.5 \mathrm{mM}$ $\mathrm{MgCl}_{2}, 0.2 \mathrm{mM}$ dNTPs, $2.5 \mathrm{U}$ of Taq DNA polymerase, and $0.1 \mu \mathrm{M}$ each of primers for iNOS, COX-2, TNF- $\alpha$, and IL-1 $\beta$. The amplification conditions and primers were the same as previously described (Lee et al., 2003a).

\section{Electrophoretic mobility shift assay}

Nuclear extracts from RAW264.7 cells were prepared as described previously (Kim et al., 2001). A double stranded NF-кB-specific oligonucleotide (5'AGTTGAGGGGACTTTCCCAGGC-3') was labeled with $\left[\gamma^{-32} \mathrm{P}\right] \mathrm{ATP}$ using T4 polynucleotide kinase and purified on a G-50 Sephadex column. The nuclear extracts (10 $\mu \mathrm{g}$ of protein) were incubated with $\sim 40,000 \mathrm{cpm}(\sim 0.5 \mathrm{ng})$ of ${ }^{32}$ P-labeled oligonucleotide for $20 \mathrm{~min}$ at room temperature as described previously (Kim et al., 2001). Samples were separated on a $5 \%$ native polyacrylamide gel. The gel was dried and subjected to autoradiography.

\section{iNOS promoter activity assay}

Transient transfection and iNOS promoter activity assay were carried out as previously described (Kim et al., 2001). A murine iNOS promoter-luciferase construct was transfected into RAW264.7 cells by the liposome method. The cells were cultured overnight in media supplemented with $10 \%$ fetal bovine serum and treated with LPS in the presence or absence of $\beta$-carotene for $12 \mathrm{~h}$. Cells were lysed with buffer containing 1\% Triton X-100, $5 \mathrm{mM}$ dithiothreitol, 50\% glycerol, $10 \mathrm{mM}$ EDTA, and $125 \mathrm{mM}$ Tris-phosphate $(\mathrm{pH} 7.8)$. Luciferase activity was measured by luminometer.

\section{Measurement of intracellular ROS}

The amount of intracellular ROS was measured by previous method (Lee et al., 2003b). RAW264.7 cells cultured on round coverslips in phenol red-free medium were treated with or without $50 \mu \mathrm{M} \beta$-carotene for $30 \mathrm{~min}$. For the last $10 \mathrm{~min}$ of stimulation, cells were incubated with $10 \mu \mathrm{M} \mathrm{DCFH}$-DA in the presence or absence of $1 \mu \mathrm{g} / \mathrm{ml}$ LPS. Then, the cells were immediately observed by confocal laser-scanning microscopy. DCF fluorescence intensities were determined from the same numbers of cells in a randomly selected area.

\section{Statistical analysis}

Data are presented as the mean $\pm S D$ of at least three separate experiments. Comparisons between two groups were analyzed using Student's $t$-test. $P$ values less than 0.05 were considered to be statistically significant.

\section{Results}

\section{$\beta$-carotene inhibits inflammatory enzyme expression}

Immune-activated macrophages up-regulate the expression of the inflammatory enzymes, such as iNOS and COX-2, which are involved in the pathogenesis of many human diseases. iNOS and COX-2 synthesize $\mathrm{NO}$ and $\mathrm{PGE}_{2}$ from L-arginine and arachidonic acid, respectively. We first performed the experiments to determine whether $\beta$-carotene regulates the production and $\mathrm{NO}$ and $\mathrm{PGE}_{2}$ in the murine macrophage cell line RAW264.7. Cells were stimulated with LPS in the presence or absence of $\beta$-carotene for $16 \mathrm{~h}$, and the levels of $\mathrm{NO}$ and $\mathrm{PGE}_{2}$ were measured in the culture medium by Griess reagents and ELISA kit, respectively. LPS-stimulated cells increased the accumulation of nitrite, a stable oxidized product of NO, and $\mathrm{PGE}_{2}$ in the culture medium while control cells did not (Figures $1 \mathrm{~A}$ and $1 \mathrm{~B}$ ). These increases were significantly reduced in a dose dependent manner by co-treatment with $\beta$-carotene with an $\mathrm{IC}_{50}$ value of $\sim 30 \mu \mathrm{M}$. No cytotoxic effect of $\beta$-carotene was observed under the same experimental condition as measured by lactate dehydrogenase release and crystal violet staining (data not shown). We next examined the effects of $\beta$-carotene on the levels of iNOS and COX-2 proteins and mRNAs in LPSstimulated cells. Western blot analyses showed that LPS-mediated increases in the protein and mRNA levels of these enzymes were suppressed in a dosedependent manner by $\beta$-carotene treatment and that $50 \mu \mathrm{M} \beta$-carotene almost completely inhibited their 
A
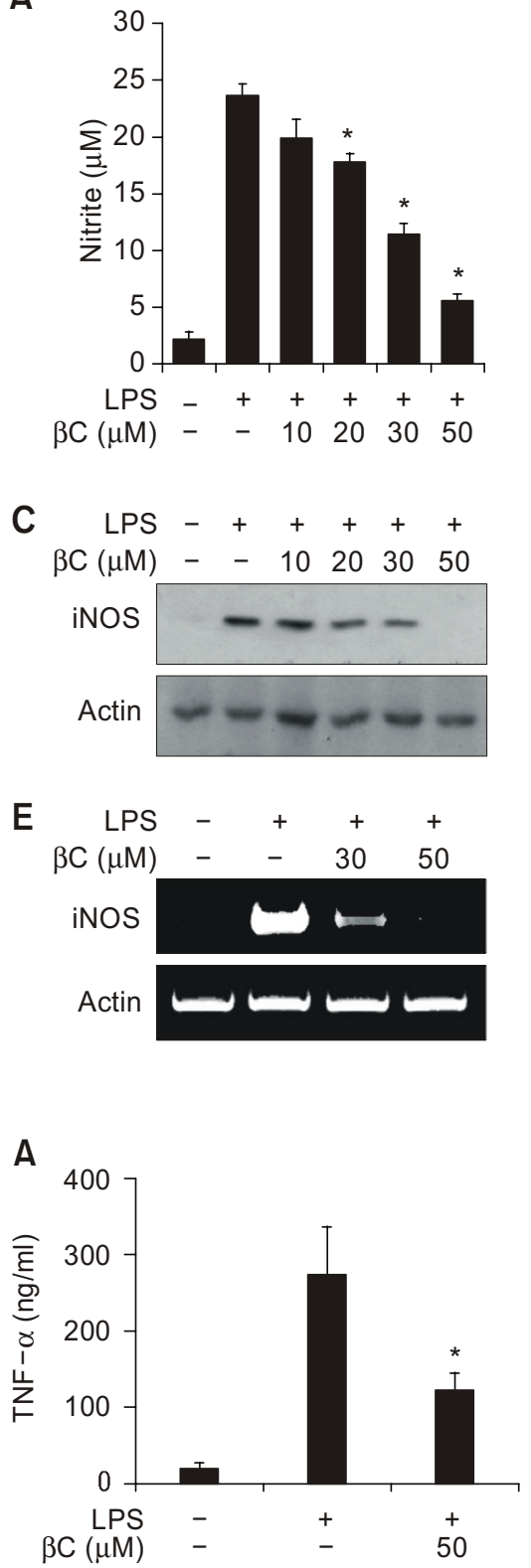

C

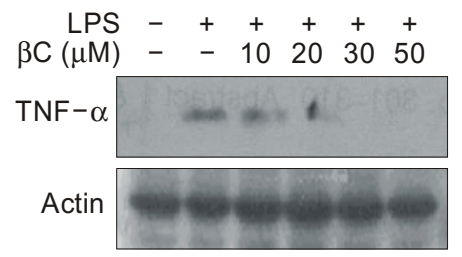

E

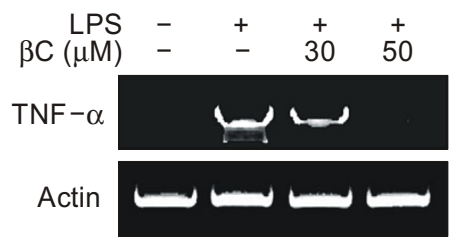

B

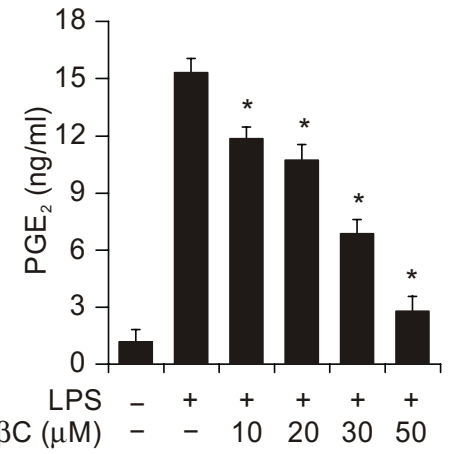

D

LPS - + + + + $\beta C(\mu \mathrm{M})-\quad-102030 \quad 50$

COX-2

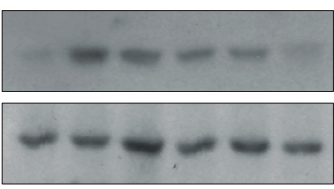

F

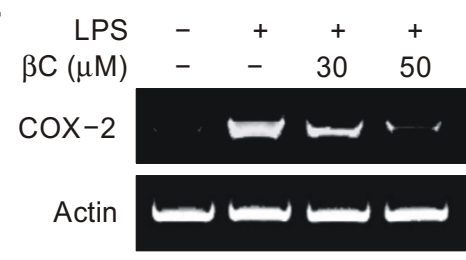

Figure 1. $\beta$-Carotene inhibits the production of $\mathrm{NO}$ and $\mathrm{PGE}_{2}$ and the expression iNOS and COX-2 in LPS-stimulated RAW264.7 cells. (A and B) RAW264.7 cells were stimulated with LPS $(1 \mu \mathrm{g} / \mathrm{ml})$ in the presence or absence of different concentrations of $\beta$-carotene $(\beta C)$. After $16 \mathrm{~h}$, the levels of nitrite and $\mathrm{PGE}_{2}$ were measured in the culture medium by Griess reagents and ELISA kit. Data shown are the mean $\pm \mathrm{SD}(n \geq 3) .{ }^{*}, P<0.01$ versus LPS alone. ( $C$ and D) After $16 \mathrm{~h}$, cells were harvested, washed twice with ice-cold PBS, and lysed by three cycles of freezing and thawing. Cytosolic extracts were prepared by centrifugation at $12,000 \mathrm{~g}$ for $20 \mathrm{~min}$. The protein levels of iNOS and COX-2 were measured by Western blot analyses using antibodies against mouse iNOS and COX-2, respectively. The membranes were rehybridized with actin antibody to verify equal loading of protein in each lane. ( $\mathrm{E}$ and $\mathrm{F}$ ) After $8 \mathrm{~h}$ stimulation, total RNAs were obtained from RAW264.7 cells using a Trizol reagent kit. The mRNA levels of iNOS and COX-2 were determined by RT-PCR analysis. Actin was used as an internal control.

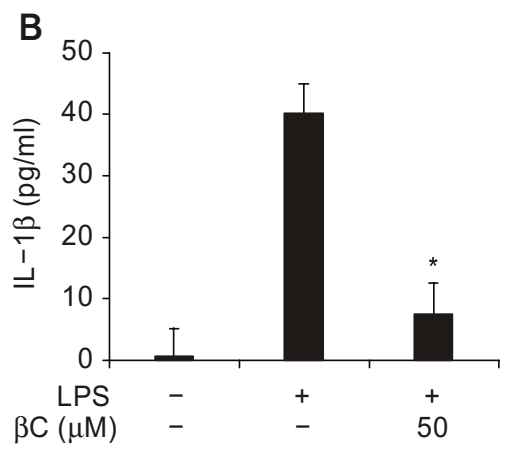

Figure 2. $\beta$-Carotene inhibits TNF- $\alpha$ and IL-1 $\beta$ production and expression in LPS-stimulated RAW264.7 cells. (A and B) RAW264.7 cells were cultured with LPS $(1 \mu \mathrm{g} / \mathrm{ml})$ in the presence or absence of indicated concentrations of $\beta$-carotene $(\beta C)$ for $12 \mathrm{~h}$. The levels of TNF- $\alpha$ and $\mathrm{IL}-1 \beta$ were determined in the culture medium using ELISA kits. Data shown are the mean $\pm S D$ $\left(n \geq 3\right.$ ). ${ }^{*}, P<0.01$ versus LPS alone. ( $C$ and D) After $8 \mathrm{~h}$, cells were harvested, washed twice with ice-cold PBS, and lysed by three cycles of freezing and thawing. Cytosolic extracts were prepared by centrifugation at $12,000 \mathrm{~g}$ for 20 min. The intracellular levels of TNF- $\alpha$ and IL-1 $\beta$ were measured by Western blot analyses using polyclonal antibodies for TNF- $\alpha$ and IL-1 $\beta$. (E and F) After $6 \mathrm{~h}$ stimulation, total RNAs were obtained from RAW264.7 cells using a Trizol reagent kit. The levels of TNF- $\alpha$ and IL-1 $\beta$ mRNAs were determined by RT-PCR analysis. Actin was used as an internal control. 
protein and mRNA levels (Figures $1 \mathrm{C}$ to $1 \mathrm{~F}$ ). These results indicates that $\beta$-carotene inhibits $\mathrm{NO}$ and $\mathrm{PGE}_{2}$ production through the suppression of iNOS and COX-2 expression at the transcriptional step in LPS-stimulated RAW264.7 macrophages, respectively.

\section{$\beta$-carotene inhibits pro-inflammatory cytokine expression in LPS-stimulated RAW264.7 cells}

We next examined whether $\beta$-carotene regulates inflammatory cytokine production. RAW264.7 cells were stimulated with LPS in the presence or absence of $\beta$-carotene and the protein levels of TNF- $\beta$ and IL-1 $\beta$ were measured in the culture medium by ELISA. Stimulation of RAW264.7 cells with LPS significantly increased the secreted TNF- $\alpha$ and IL-1 $\beta$ levels in the culture medium, and these increases were effectively inhibited by co-treatment with $50 \mu \mathrm{M}$ $\beta$-carotene (Figures $2 \mathrm{~A}$ and $2 \mathrm{~B}$ ). It has been shown that TNF- $\alpha$ and IL-1 $\beta$ are expressed as inactive pro-forms, cleaved into the active forms by TNF- $\alpha-$ converting enzyme and interleukin- $1 \beta$-converting enzyme, and secreted into the culture medium or extracellular fluids (Thornberry et al., 1992; Black et al., 1997). We next examined whether $\beta$-carotene inhibits the intracellular protein levels of pro-TNF- $\alpha$ and pro-IL-1 $\beta$. Western blot analyses showed that $\beta$-carotene treatment suppressed the intracellular levels of these pro-forms in a dose-dependent manner (Figures 2C and 2D). Furthermore, $\beta$-carotene inhibited the mRNA levels of these cytokines in RAW264.7 cells stimulated with LPS (Figures 2C and $2 F)$. These results indicate that $\beta$-carotene inhibits the expression of pro-inflammatory TNF- $\beta$ and IL-1 $\beta$.

\section{$\beta$-carotene inhibits NO production and inflammation-associated gene expression in LPS-stimulated peritoneal macrophages}

We further examined the effects of $\beta$-carotene on iNOS expression in primary cultured murine peri-
A

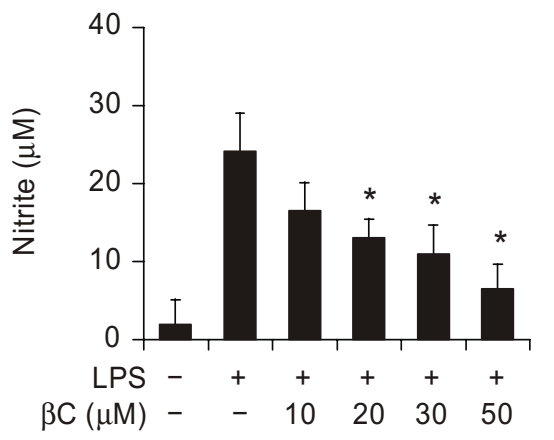

B

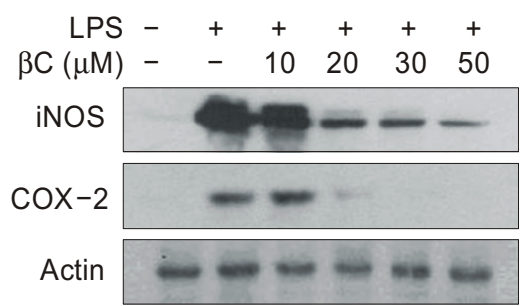

C

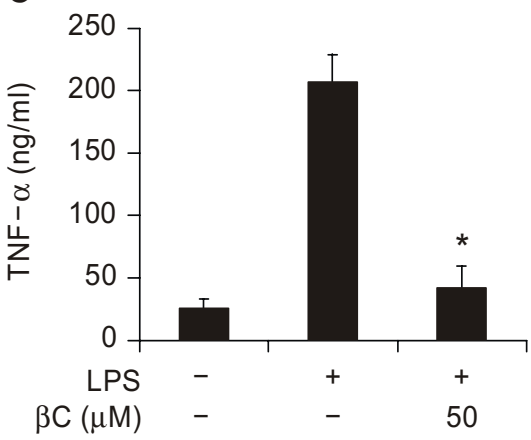

D

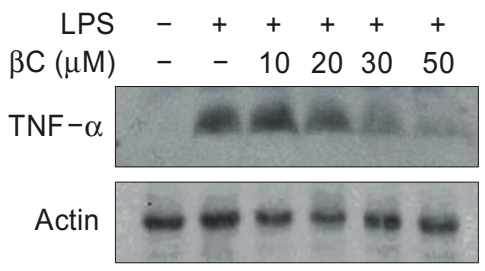

E

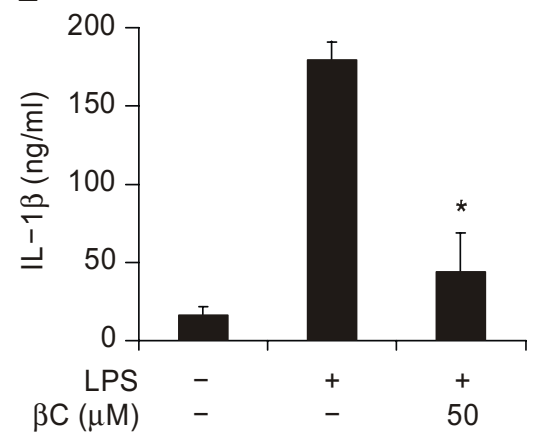

$\mathbf{F}$

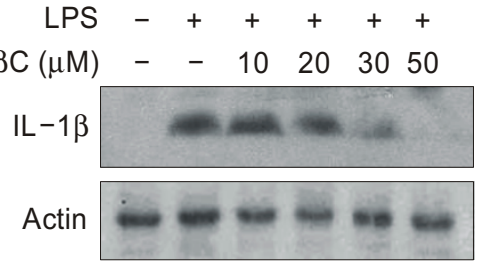

Figure 3. $\beta$-Carotene inhibits inflammatory gene expression in primary peritoneal macrophages. Peritoneal macrophages cultured in 6-well culture dishes were treated with LPS in the presence or absence of $\beta$-carotene $(\beta C)$ for $16 \mathrm{~h}$. (A) The levels of nitrite were measured in the culture media by Griess reagents. Data shown are the mean $\pm \mathrm{SD}(n=3)$. ${ }^{*}, P<0.01$ versus LPS alone. (B) Cytosolic extracts were prepared by three cycles of freezing and thawing and centrifugation at $12,000 \mathrm{~g}$ for $20 \mathrm{~min}$. The levels of iNOS and COX-2 were measured by Western blot analyses using antibodies against mouse iNOS and COX-2. The membranes were rehybridized with actin antibody to verify equal loading of protein in each lane. (C and E) The levels of TNF- $\alpha$ and IL-1 $\beta$ were determined in culture medium using ELISA kits. Data shown are the mean \pm SD $(n \geq 3)$. *, $P<0.01$ versus LPS alone. ( $(\mathrm{a}$ and $\mathrm{F}$ ) Cytosolic extracts were prepared by three cycles of freezing and thawing and centrifugation at $12,000 \mathrm{~g}$ for $20 \mathrm{~min}$. The intracellular levels of TNF- $\alpha$ and IL-1 $\beta$ were measured by Western blot analyses using antibodies against mouse TNF- $\alpha$ and IL-1 $1 \beta$. The membranes were rehybridized with actin antibody to verify equal loading of protein in each lane. 
toneal macrophages. For this experiment, peritoneal macrophages isolated from female BALB/c mice were cultured in 6-well plates overnight and stimulated with LPS in the presence or absence of $\beta$-carotene, and NO production and expression of inflammation-associated genes were determined. LPS-stimulated peritoneal macrophages increased NO production and the expression of iNOS and COX-2 proteins, and these increases were significantly inhibited in a dose-dependent manner by co-treatment with $\beta$-carotene (Figures $3 \mathrm{~A}$ and $3 \mathrm{~B}$ ). Moreover, treatment with $\beta$-carotene inhibited the increases in both the secreted and pro-forms of TNF- $\alpha$ and IL-1 $\beta$ in LPS-stimulated primary macrophages (Figures $3 \mathrm{C}$ to $3 \mathrm{~F}$ ).

\section{$\beta$-carotene decreases the production of NO, $\mathrm{PGE}_{2}, \mathrm{TNF}-\alpha$, and IL-1 $\beta$ in vivo}

The data shown above provide evidence for a distinct anti-inflammatory action of $\beta$-carotene in RAW264.7 cells and peritoneal macrophages. To verify the in vivo relevance of $\beta$-carotene's in vitro anti-inflammatory role, we examined its effect on the production of the inflammation-associated mediators and gene products, such as NO, PGE 2 , TNF- $\alpha$, and IL-1 $\beta$, in LPS-administrated mice as a well-established septic animal model. Serum levels of NOx and $\mathrm{PGE}_{2}$ were significantly elevated by LPS administration compared with those of control mice injected with saline or $\beta$-carotene alone, and these increases were reduced by treatment with $\beta$-carotene (Figures $4 A$ and $4 B$ ). We next examined the regulatory effects of $\beta$-carotene on the serum levels of TNF- $\alpha$ and $\mathrm{IL}-1 \beta$ in LPS-administrated mice. LPS administration increased the serum levels of these cytokines, while control mice treated with saline or $\beta$-carotene alone did not (Figures 4C and D). LPSinduced increases in the serum levels of TNF- $\alpha$ and IL-1 $\beta$ were significantly suppressed by co-administration with $\beta$-carotene. These results indicate that $\beta$-carotene can inhibit the production of inflammatory mediators in in vivo pathologic inflammatory conditions.
A

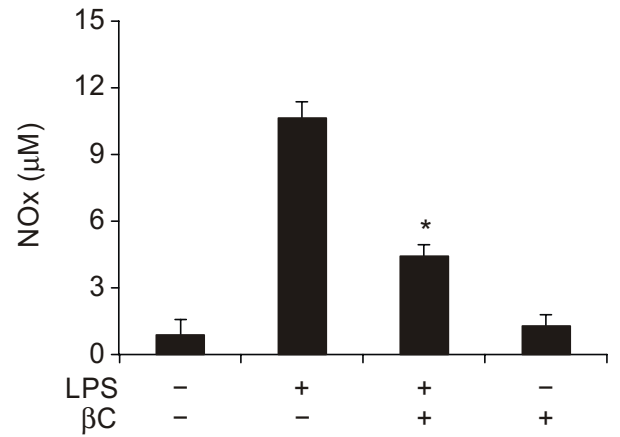

C

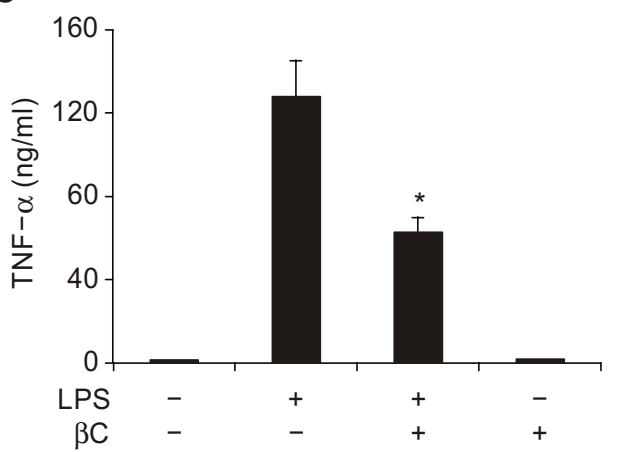

B

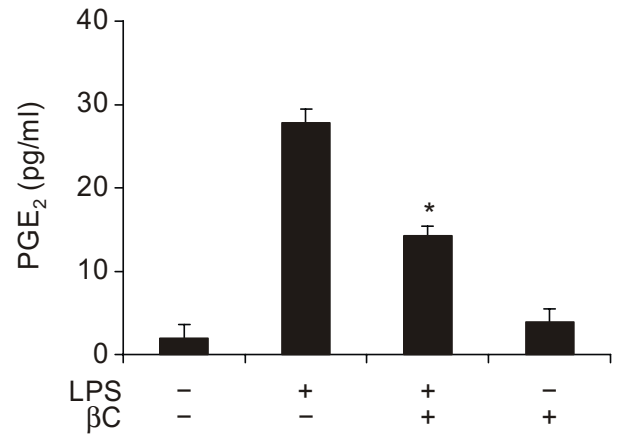

D

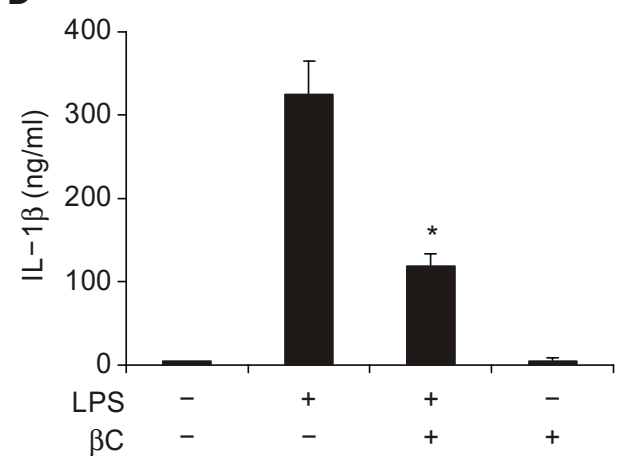

Figure 4. $\beta$-Carotene decreases the production of inflammatory mediators in vivo. Mice were injected i.p. with LPS (4 $\mathrm{mg} / \mathrm{Kg}$ ) following pretreatment with or without $\beta$-carotene $(\beta C, 10 \mathrm{mg} / \mathrm{Kg})$. After $12 \mathrm{~h}$ of LPS treatment, whole blood was collected by cardiac puncture and serum was obtained by centrifugation at $12,000 \mathrm{~g}$ for $20 \mathrm{~min}$. (A) The serum levels of nitrite plus nitrate (NOx) were measured using a nitrate assay kit. The levels of PGE $2(B), T N F-\alpha(C)$, and IL-1 $\beta$ (D) were determined by ELISA kits. All data shown are the mean $\pm \mathrm{SD}(n=6) .{ }^{*}, P<0.01$ versus LPS alone. 


\section{$\beta$-carotene suppresses NF- $\mathrm{kB}$ activation and iNOS promoter activity by inhibiting IKB- $\alpha$ degradation and nuclear translocation of NF-KB}

It is well known that NF-KB is an important transcription factor for the inducibility of various inflammatory genes including iNOS, COX-2, TNF- $\alpha$, and $\mathrm{IL}-1 \beta$ in macrophages treated with LPS (Xie et al., 1994; Rhodus et al., 2005). To investigate whether $\mathrm{NF}-\mathrm{KB}$ is an important target for the anti-inflammatory action of $\beta$-carotene in macrophages, we examined the effect of $\beta$-carotene on NF-KB activation by performing an electrophoretic mobility shift assay. The nuclear extract from LPS-stimulated macrophages showed an increase in NF-KB-DNA binding activity, while this activity was not seen in unstimulated cells
(Figure 5A). The binding activity was suppressed in a dose-dependent manner by treatment with $\beta$-carotene, and specific interaction between DNA and $\mathrm{NF}-\kappa \mathrm{B}$ was demonstrated by a competitive assay with a 100 -fold excess of unlabelled oligonucleotide (cold probe), suggesting that $\beta$-carotene inhibits the expression of the inflammatory genes through the

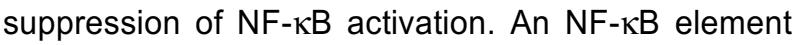
at -85 bp upstream in the murine iNOS promoter has been shown to be the major regulatory factor for murine iNOS gene expression in response to LPS (Xie et al., 1994). We examined whether $\beta$-carotene suppresses iNOS promoter activity through the inhibition of NF-KB activation. Transient transfection in RAW264.7 cells was performed with a murine
A

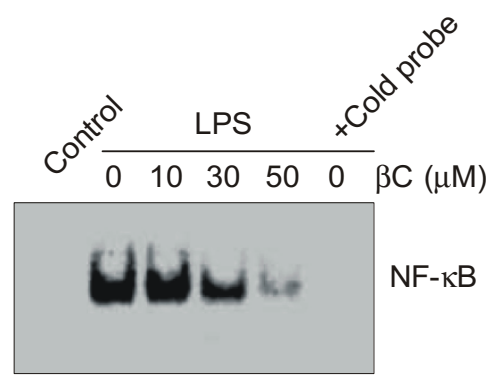

C

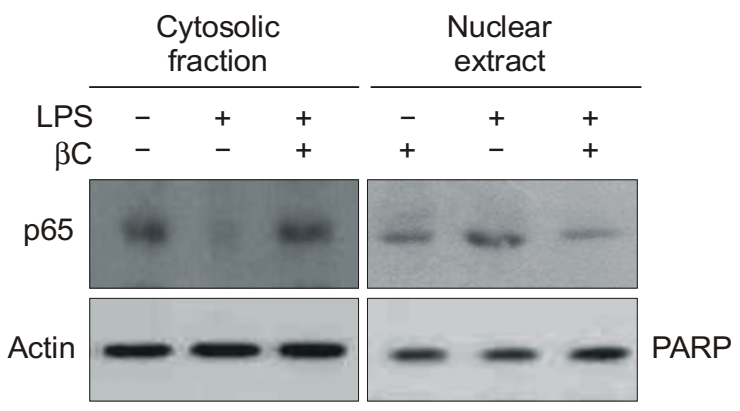

B

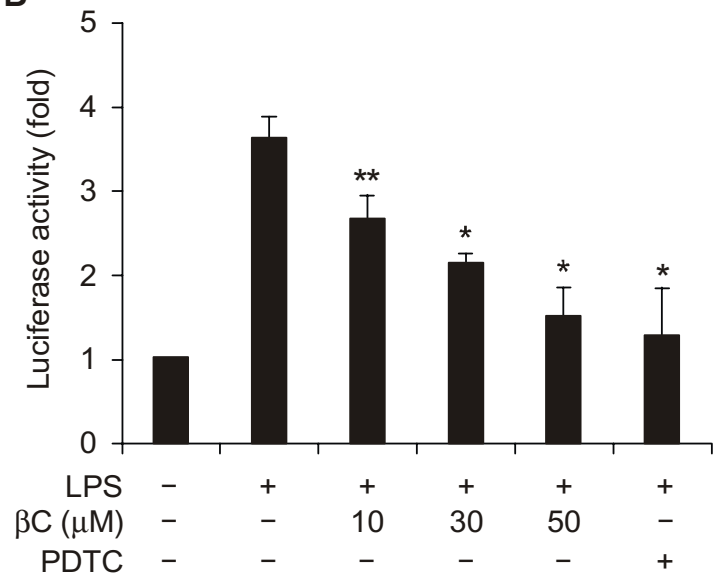

Figure 5. $\beta$-Carotene suppresses NF- $\kappa B$ activation and iNOS promoter activity. (A) RAW264.7 cells were treated with LPS in the presence or absence of $\beta$-carotene $(\beta C)$ for $2 \mathrm{~h}$. Cells were harvested, and nuclear extracts were prepared. Nuclear NF-KB activity was analyzed by electrophoretic mobility shift assay in the presence or absence of an excess amount of cold probe. (B) RAW264.7 cells were transiently transfected by a lipofectamine method with murine iNOS promoter. Cells were treated with LPS in the presence or absence of indicated concentrations of $\beta$-carotene or PDTC $(10 \mu \mathrm{M})$ for $12 \mathrm{~h}$. Luciferase activity in the cell extracts was measured by luminometer. Data shown are the mean $\pm \operatorname{SD}(n=3)$. ${ }^{*}, P<0.05$; ${ }^{*}, P<0.01$ versus LPS alone. (C) Cells were incubated with LPS in the presence or absence of $\beta$-carotene $(50 \mu \mathrm{M})$ for $2 \mathrm{~h}$. Cells were harvested, washed with ice-cold PBS, and resuspended in nuclear extraction buffer. Cytosolic fractions and nuclear extracts were prepared as described in the Method section. Both samples were separated on SDS-PAGE, and the NF-KB p65 subunit was visualized by Western blot analysis. The blot was rehybridized with antibodies for actin and PARP to verify equal loading of protein in each lane. (D) Whole cell lysates from RAW264.7 cells treated with LPS in the presence or absence of $\beta$-carotene $(50 \mu \mathrm{M})$ for 30 min were separated in SDS-PAGE. IKB $\alpha$ protein was visualized by Western blot analysis using an antibody against IKB $\alpha$. 
iNOS promoter construct (piNOS-Luc) by lipofection. Treatment of the transfected cells with LPS resulted in about a 3.6-fold increase in luciferase activity (Figure 5B). This increase was suppressed in a dose-dependent manner by increasing concentrations of $\beta$-carotene and the addition of the NF- $\kappa B$ inhibitor pyrrolidine dithiocarbamate (PDTC). The translocation of NF- $\kappa B$ to the nucleus is preceded by the phosphorylation and proteolytic degradation of $\mathrm{I} \kappa \mathrm{B}-\alpha$ (Traenckner et al., 1995; Butcher et al., 2001). To determine whether the inhibitory effect of $\beta$-carotene on LPS-induced NF-KB activation was due to inhibition of $\mathrm{I} \kappa \mathrm{B} \alpha$ degradation and $\mathrm{NF}-\kappa \mathrm{B}$ translocation, we determined the cytosolic and nuclear NF-кB p65 subunit levels following treatment of LPS in the presence or absence of $\beta$-carotene. LPS treatment decreased the cytosolic p65 subunit level, resulting in an increase in the nuclear p65 level, while this subunit was mostly present in the cytosol from control cells (Figure 5C). $\beta$-carotene treatment inhibited LPS-induced translocation of the cytosolic p65 subunit to the nuclei. We next examined the effect of $\beta$-carotene on the proteolytic degradation of $1 \kappa \mathrm{B} \alpha$. LPS treatment significantly decreased the $1 \kappa \mathrm{B} \alpha$ protein level within 30 min compared with control, and this effect was significantly blocked by $\beta$-carotene treatment (Figure
A

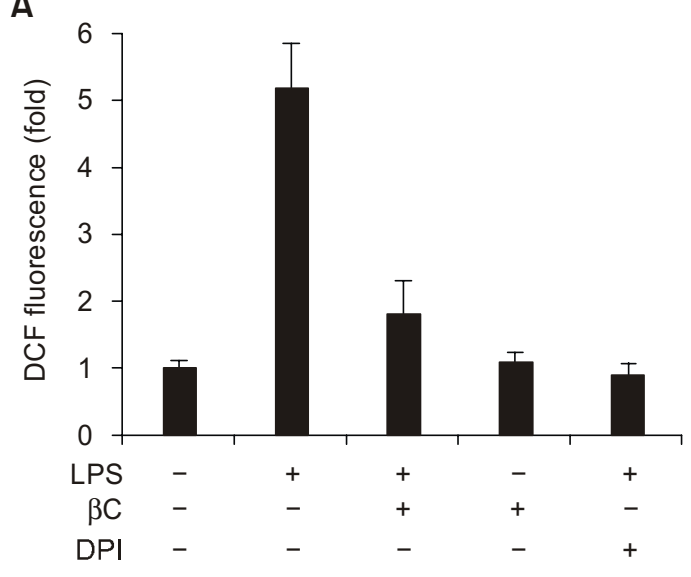

C

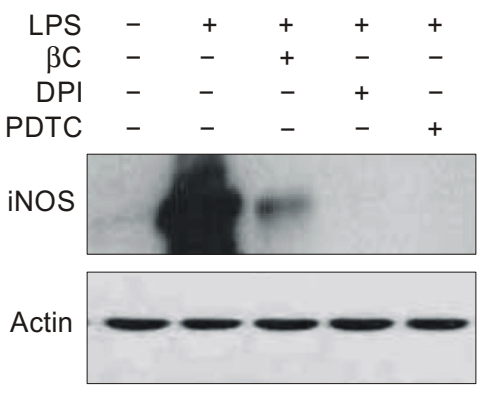

B

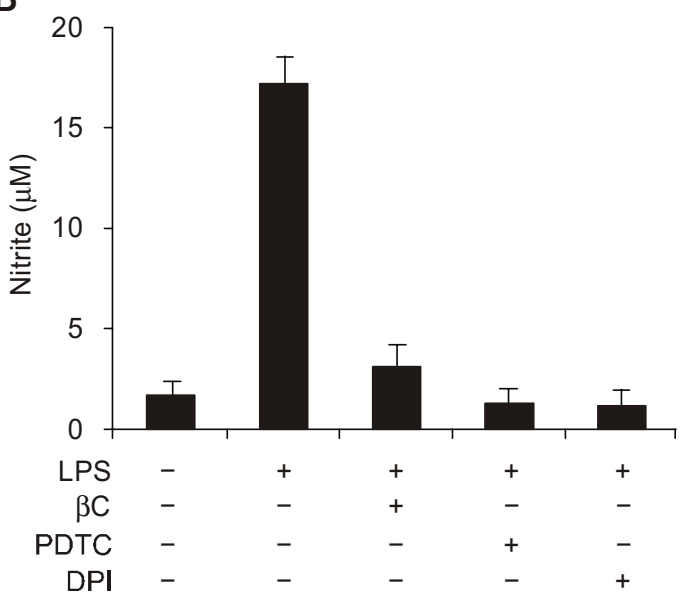

D

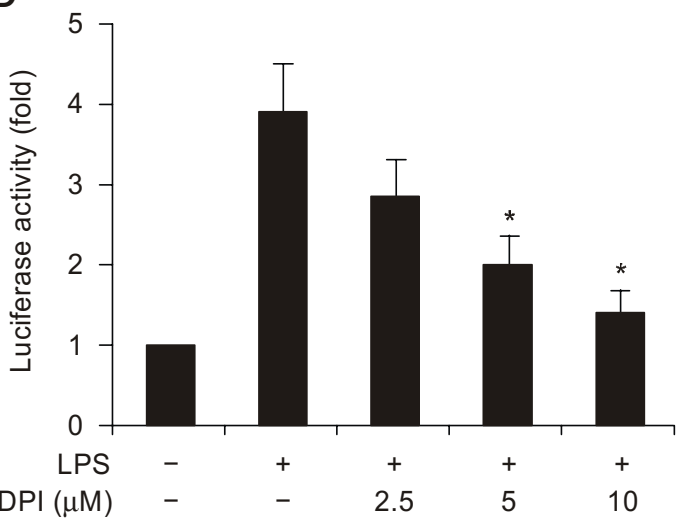

Figure 6. $\beta$-Carotene, NADPH oxidase inhibitor, and PDTC suppress the intracellular ROS level, iNOS expression, and iNOS promoter activity in RAW264.7 cells. RAW264.7 cells were treated with LPS in the presence or absence of $\beta$-Carotene $(\beta C, 50 \mu \mathrm{M})$, DPI $(10 \mu \mathrm{M})$, and PDTC $(15 \mu \mathrm{M})$. (A) After 30 min incubation, cells were incubated with $\mathrm{DCFH}_{2}$-DA $(5 \mu \mathrm{M})$ for an additional 30 min. Cells were washed twice with PBS, and the intracellular levels of ROS were analyzed by confocal microscope. DCF fluorescence intensities were determined from the same numbers of cells in randomly selected area. Data shown are the mean \pm SD $(n \geq 3)$. (B) After $16 \mathrm{~h}$ incubation, the levels of nitrite were measured in culture medium by Griess reagents. Data shown are the mean \pm SD $(n \geq 3)$. (C) The iNOS level was determined by Western blot analysis as described in Figure 1. (D) RAW264.7 cells were transiently transfected by a lipofectamine method with murine iNOS promoter. Cells were treated with LPS in the presence or absence of indicated concentrations of DPI for $12 \mathrm{~h}$. Luciferase activity in the cell extracts was measured by luminometer. Data shown are the mean $\pm \mathrm{SD}(n \geq 3)$. ${ }^{*}, P<0.01$ versus LPS alone. 
5D). The results suggest that $\beta$-carotene inhibits both the LPS-induced translocation of the p65 subunit to the nucleus and the degradation of $1 \kappa \mathrm{B} \alpha$, indicating that the major target of $\beta$-carotene suppression of NF- $\kappa B$ activation may be the inhibition of $1 \kappa B \alpha$ degradation.

\section{$\beta$-Carotene and NADPH oxidase inhibitor suppress LPS-induced increase in ROS level, iNOS expression, and iNOS promoter activity}

Macrophages stimulated with LPS generate ROS via the activation of a membrane-bound NADPH oxidase (Bokoch and Knaus, 2003), and ROS plays an important role in NF-KB activation (Flohe et al., 1997). These observations indicate that antioxidant chemicals and enzymes inhibit NF- $\kappa B$ activation and subsequently suppress NF- $\kappa B$-dependent gene expression (Han et al., 2001). We examined whether $\beta$-carotene inhibits ROS generation and NO production in RAW264.7 cells stimulated with LPS. Treatment with $\beta$-carotene as well as the NADPH oxidase inhibitor diphenylene iodonium (DPI) significantly reduced the intracellular levels of ROS in RAW264.7 cells stimulated with LPS (Figure 6A). Moreover, treatment with $\beta$-carotene, DPI, and PDTC suppressed the LPS-induced increase in NO production and iNOS expression compared with the control cells (Figures $6 \mathrm{~B}$ and $6 \mathrm{C}$ ). Since $\beta$-carotene inhibited NF- $\mathrm{KB}$ activation and iNOS promoter activity (Figure $5)$, we next examined whether DPI regulates iNOS promoter activity. Figure $6 \mathrm{D}$ showed that treatment with DPI suppressed iNOS promoter activity in a concentration-dependent manner as both $\beta$-carotene and PDTC did, as shown in Figure 5B. This result suggests that the antioxidant activity of $\beta$-carotene contributes to the suppression of $N F-\kappa B$-dependent iNOS expression.

\section{Discussion}

$\beta$-Carotene is a major antioxidant present in a range of fresh fruits and vegetables. This compound is known to take part in protecting animals against damage from free radicals and singlet oxygen reactive species. The antioxidant properties of $\beta$-carotene have been implicated in the molecular basis for preventing several diseases, primarily owing to the putative role of oxidative stress in disease initiation and progression. It has been demonstrated that $\beta$-carotene may suppress in vivo oxidative stressdependent lipid peroxidation (Everett et al., 1996), carcinogenesis (Witschi, 2005), and inflammation (Curran et al., 2000). Inflammation is a complex process and involves production of various inflam- matory mediators, such as NO, cytokines, ROS, and bioactive lipid metabolites, which are involved in the development of inflammatory diseases. LPS, a potent immune activator, induces septic shock syndrome through the production of many inflammatory mediators, such as NO, TNF- $\alpha$, IL- $1 \beta$, prostanoids, and leukotrienes (Everett et al., 1996; Kim et al., 2001) by activating immune cells including macrophages. Since activated macrophages result in the increases in NF-kB-dependent inflammatory mediators, both $N F-\kappa B$ activation and the inflammatory gene expression are well-known biological markers for inflammatory responses and its level is highly correlated with the pathogenesis of many acute and chronic human inflammatory diseases, including asthma, rheumatoid arthritis, inflammatory bowel disease, and endotoxemia-induced multiple organ injury (Barnes and Karin, 1997; Guzik et al., 2003). Thus, the suppression of NF-kB-dependent inflammatory gene expression may be an effective therapeutic strategy for preventing inflammatory processes and diseases.

The present study was undertaken to elucidate the biological and pharmacological effect of $\beta$-carotene on in vitro and in vivo production of inflammatory cytokines and mediators. We also investigated the mechanism for the molecular action of $\beta$-carotene, which is associated with the suppression of NF-KB activation. Although treatment of human leukemic cells $(\mathrm{HL}-60)$ with $\beta$-carotene alone can induce NF- $\mathrm{KB}$ activation by a significant increase in ROS production (Palozza et al., 2003), we here showed that $\beta$-carotene inhibited the NF- $\mathrm{KB}$-dependent expression of inflammatory genes, such as TNF- $\alpha, \mathrm{IL}-1 \beta$, iNOS, and COX-2, and production of $\mathrm{NO}$ and $\mathrm{PGE}_{2}$ in LPS-stimulated macrophages and LPS-administrated animals. These observations suggest that $\beta$-carotene may act as a dual functional molecule: the activation of NF-KB in tumor cells without any stimulation and the inhibition of NF-KB activation in immune cells stimulated with immune stimulants including LPS. In this study, we demonstrated that the molecular mechanism by which $\beta$-carotene inhibits the expression of these inflammatory mediators appeared to involve the inhibition of NF- $\mathrm{KB}$ activation by blocking LPS-induced $I \kappa B \alpha$ degradation and nuclear translocation of the cytosolic NF- $\mathrm{KB}$ p65 subunit. Moreover, $\beta$-carotene showed to act as a potent antioxidant activity by inhibiting intracellular ROS accumulation in LPS-stimulated macrophages. This antioxidant activity of $\beta$-carotene is likely to suppress $\mathrm{NF}-\kappa \mathrm{B}$ activation and NF- $\mathrm{BB}$-dependent inflammatory gene expression. These results evidently suggest that $\beta$-carotene may prevent organ or tissue injury during acute endotoxemia or sepsis by suppressing NF-kBmediated inflammatory gene expression.

Activated macrophages produce a large amount of 
the pro-inflammatory cytokines TNF- $\alpha$ and IL-1 $\beta$ and induce the expression of COX-2 and iNOS, which catalyze the biosynthesis of $\mathrm{PGE}_{2}$ and $\mathrm{NO}$, respectively. These inflammatory cytokines and mediators play an important role in the pathogenesis of acute and chronic inflammatory diseases and organ injury (Simons et al., 1996; Guslandi, 1998). It has been shown that anti-inflammatory drugs such as dexamethasone, prednisone, sulfasalazine, and aspirin prevent the development of human inflammatory diseases by suppressing the production of proinflammatory cytokines and expression of COX-2 and iNOS in immune-activated macrophages (Leach et al., 1998; Makarov, 2000; Tak et al., 2001). Previous studies have demonstrated that the suppression of biological activities of TNF- $\alpha, \mathrm{IL}-1 \beta, \mathrm{COX}-2$, and iNOS by neutralizing antibodies, selective inhibitors or gene targeting have led to a dramatic improvement in the local inflammation and progression of rheumatoid arthritis (Tak et al., 2001) and atherosclerosis (Napoli and Ignarro, 2001) and the beneficial effects for septic shock (Szabo et al., 1994). It indicates that a potent drug with anti-inflammatory activity provides the beneficial advantage for treatment of inflammatory disorders. Our study showed that $\beta$-carotene effectively inhibited the production of the inflammatory cytokines and enzymes in a dose dependent manner with an $\mathrm{IC}_{50}$ value of $\sim 30 \mu \mathrm{M}$ in LPS-stimulated macrophages as well as in a septic mouse model. These results suggest that $\beta$-carotene has therapeutic potential in inflammatory diseases.

Activation of the transcription factor NF- $\mathrm{KB}$ by a wide variety of agents, such as ROS, TNF- $\beta$, and LPS, plays a crucial role in the expression of the inflammatory genes, including iNOS, COX-2, TNF- $\beta$, and IL-1 $\beta$, which contain NF-KB-binding motifs within their respective promoters (Xie et al., 1994; Rhodus et al., 2005). Thus, the abnormal, constitutive activation of $\mathrm{NF}-\mathrm{KB}$ has known to be associated with a number of chronic inflammatory diseases, such as asthma, rheumatoid arthritis, atherosclerosis, and inflammatory bowl disease. It has been shown that antiinflammatory drugs including dexamethasone suppress the expression of inflammation-associated genes by the inhibition of the NF-KB signaling pathway (van der Saag et al., 1996; Makarov, 2000). This fact indicates that the inhibition of the NF- $\kappa B$ pathway is an extremely attractive target for the intervention of inflammatory processes. In addition a role of $\mathrm{NF}-\kappa \mathrm{B}$ activation has been implicated in the pathogenesis of human diseases characterized by increases in the host immune and inflammatory response. Constitutive activation of the NF-KB pathway has also been implicated in the pathogenesis of some human cancers (Chiao et al., 2002). Furthermore, activation of the NF- $\mathrm{KB}$ pathway may be involved in the initiation or potentiation of neuritic plaques and neuronal apoptosis during the early phases of Alzheimer's disease (Kaltschmidt et al., 1999). Thus, it suggests that potential inhibitors of NF- $\kappa B$ pathway can be used for prevention of inflammation-associated human diseases, cancer, and Alzheimer's disease. Our previous study has been shown that the antioxidant astaxanthin acts as an inhibitor of the NF- $\kappa B$ pathway (Lee et al., 2003a). In fact, the present study demonstrated that relatively low concentrations of $\beta$-carotene (30 to $50 \mu \mathrm{M}$ ) blocked NF- $\mathrm{KB}$ activation and inhibited iNOS promoter activity. It has been shown that the activation and nuclear translocation of $N F-\kappa B$ is regulated by the proteolytic degradation $I \kappa B$ after its phosphorylation and ubiquitination (de Martin et al., 1993), indicating that $I \kappa B$ degradation is a critical step for NF-кB activation. Our results showed that $\beta$-carotene inhibited $I \kappa B$ degradation and subsequently blocked nuclear translocation of the NF- $\kappa B$ p65 subunit, resulting in the suppression of iNOS promoter activity. Thus, the molecular mechanism of $\beta$-carotene's anti-inflammatory effect is likely associated with the inhibition of NF-KB activation through the suppression of $\mathrm{I} \kappa \mathrm{B} \alpha$ degradation.

LPS stimulates ROS via the activation of NADPH oxidase in macrophages. ROS is thought to be involved in inflammatory gene expression through the redox-based activation of NF- $\mathrm{KB}$ signaling pathway (Kabe et al., 2005). It has been shown that antioxidants, such as PDTC, N-acetyl-L-cysteine, and astaxanthin, inhibit inflammatory gene expression and NO production by suppressing NF- $\mathrm{BB}$ activation through the removal of ROS (Meyer et al., 1992; Schreck et al., 1992; Lee et al., 2003a). Therefore, ROS may play an important role in NF- $\kappa B$ activation and pro-inflammatory cytokine production in LPSstimulated macrophages, probably by increasing tyrosine phosphorylation of IKK via the activation of protein kinase D (Storz and Toker, 2003). It also suggests that intracellular oxidative stress is an activating signal of NF- $\mathrm{KB}$-dependent inflammatory gene expression. Our data demonstrated that $\beta$-carotene significantly suppressed LPS-induced increases in intracellular ROS accumulation, iNOS expression, NO production, and iNOS promoter activity in macrophages as the NADPH oxidase inhibitor DPI and PDTC did, indicating that ROS participated in NF$\kappa \mathrm{B}-$ dependent iNOS expression and NO production. Therefore, the molecular mechanism by which $\beta$ carotene inhibits NF- $\mathrm{KB}$ activation is likely to block I $\mathrm{B}$ phosphorylation and degradation, probably by suppressing redox-based IKK activation.

Taken together, $\beta$-carotene inhibited the production of inflammation-associated gene expression and mediators via the suppression of $I \kappa B$ degradation and subsequent NF- $\mathrm{KB}$ activation by scavenging intra- 
cellular ROS. It suggests that $\beta$-carotene may be beneficial in the prevention or treatment of human inflammatory diseases, such as sepsis, rheumatoid arthritis, and atherosclerosis.

\section{Acknowledgment}

We thank Mrs. Elaine Por for helpful comments and critical reading of this manuscript. This work was supported by Vascular System Research Center grant form Korea Science \& Engineering Foundation.

\section{References}

Barnes PJ, Karin M. Nuclear factor- $\kappa B$ : a pivotal transcription factor in chronic inflammatory diseases. $N$ Engl $\mathrm{J}$ Med 1997;336:1066-71

Black RA, Rauch CT, Kozlosky CJ, Peschon JJ, Slack JL, Wolfson MF, Castner BJ, Stocking KL, Reddy P, Srinivasan S, Nelson N, Boiani N, Schooley KA, Gerhart M, Davis R, Fitzner JN, Johnson RS, Paxton RJ, March CJ, Cerretti DP. A metalloproteinase disintegrin that releases tumournecrosis factor- $\alpha$ from cells. Nature 1997;385:729-33

Bokoch GM, Knaus UG. NADPH oxidases: not just for leukocytes anymore! Trends Biochem Sci 2003;28:502-8

Butcher BA, Kim L, Johnson PF, Denkers EY. Toxoplasma gondii tachyzoites inhibit proinflammatory cytokine induction in infected macrophages by preventing nuclear translocation of the transcription factor NF- $\kappa$ B. J Immunol 2001;167: 2193-201

Chiao PJ, Na R, Niu J, Sclabas GM, Dong Q, Curley SA. Role of Rel/NF-KB transcription factors in apoptosis of human hepatocellular carcinoma cells. Cancer 2002;95: 1696-705

Curran FJ, Sattar N, Talwar D, Baxter JN, Imrie CW. Relationship of carotenoid and vitamins $A$ and $E$ with the acute inflammatory response in acute pancreatitis. $\mathrm{Br} \mathrm{J}$ Surg 2000;87:301-5

de Martin R, Vanhove B, Cheng Q, Hofer E, Csizmadia V, Winkler $\mathrm{H}$, Bach $\mathrm{FH}$. Cytokine-inducible expression in endothelial cells of an I $\kappa \mathrm{B} \alpha$-like gene is regulated by $\mathrm{NF} \kappa \mathrm{B}$. EMBO J 1993;12:2773-9

Dichtl W, Nilsson L, Goncalves I, Ares MP, Banfi C, Calara F, Hamsten A, Eriksson P, Nilsson J. Very low-density lipoprotein activates nuclear factor- $\kappa B$ in endothelial cells. Circ Res 1999;84:1085-94

Everett SA, Dennis MF, Patel KB, Maddix S, Kundu SC, Willson RL. Scavenging of nitrogen dioxide, thiyl, and sulfonyl free radicals by the nutritional antioxidant $\beta$-Carotene. J Biol Chem 1996;271:3988-94

Flohe L, Brigelius-Flohe R, Saliou C, Traber MG, Packer L. Redox regulation of $\mathrm{NF}-\kappa \mathrm{B}$ activation. Free Radic Biol Med $1997 ; 22: 1115-26$

Gilroy DW, Lawrence T, Perretti M, Rossi AG. Inflammatory resolution: new opportunities for drug discovery. Nat Rev Drug Discov 2004;3:401-16

Guslandi M. Nitric oxide and inflammatory bowel diseases. Eur J Clin Invest 1998;28:904-7

Guzik TJ, Korbut R, Adamek-Guzik T. Nitric oxide and superoxide in inflammation and immune regulation. J Physiol Pharmacol 2003;54:469-87

Han YJ, Kwon YG, Chung HT, Lee SK, Simmons RL, Billiar TR, Kim YM. Antioxidant enzymes suppress nitric oxide production through the inhibition of NF- $\mathrm{KB}$ activation: role of $\mathrm{H}_{2} \mathrm{O}_{2}$ and nitric oxide in inducible nitric oxide synthase expression in macrophages. Nitric Oxide2001; 5:504-13

Heiss E, Herhaus C, Klimo K, Bartsch H, Gerhauser C. Nuclear factor $\kappa B$ is a molecular target for sulforaphanemediated anti-inflammatory mechanisms. J Biol Chem 2001; 276: 32008-15

Heliovaara M, Knekt P, Aho K, Aaran RK, Alfthan G., Aromaa A. Serum antioxidants and risk of rheumatoid arthritis. Ann Rheum Dis 1994;53:51-3

Kabe Y, Ando K, Hirao S, Yoshida M, Handa H. Redox regulation of NF- $\mathrm{KB}$ activation: distinct redox regulation between the cytoplasm and the nucleus. Antioxid Redox Signal 2005;7: 395-403

Kaltschmidt B, Uherek M, Wellmann H, Volk B, Kaltschmidt C. Inhibition of NF-KB potentiates amyloid beta-mediated neuronal apoptosis. Proc Natl Acad Sci USA 1999;96: 9409-14

Kim KM, Chun SB, Koo MS, Choi WJ, Kim TW, Kwon YG, Chung HT, Billiar TR, Kim YM. Differential regulation of NO availability from macrophages and endothelial cells by the garlic component S-allyl cysteine. Free Radic Biol Med 2001;30:747-56

Kim YM, Talanian RV, Billiar TR. Nitric oxide inhibits apoptosis by preventing increases in caspase-3-like activity via two distinct mechanisms. J Biol Chem 1997;272:31138-48

Leach M, Hamilton LC, Olbrich A, Wray GM, Thiemermann C. Effects of inhibitors of the activity of cyclo-oxygenase-2 on the hypotension and multiple organ dysfunction caused by endotoxin: a comparison with dexamethasone. $\mathrm{Br} \mathrm{J}$ Pharmacol 1998;124:586-92

Lee SJ, Bai SK, Lee KS, Namkoong S, Na HJ, Ha KS, Han JA, Yim SV, Chang K, Kwon YG, Lee SK, Kim YM. Astaxanthin inhibits nitric oxide production and inflammatory gene expression by suppressing IKB kinase-dependent NF- $\kappa B$ activation. Mol Cells 2003a;16:97-105

Lee ZW, Kwon SM, Kim SW, Yi SJ, Kim YM, Ha KS. Activation of in situ tissue transglutaminase by intracellular reactive oxygen species. Biochem Biophys Res Commun 2003b;305:633-40

Makarov SS. NF- $\kappa B$ as a therapeutic target in chronic inflammation: recent advances. Mol Med Today 2000;6: $441-8$

Meyer M, Caselmann WH, Schluter V, Schreck R, Hofschneider $\mathrm{PH}$, Baeuerle PA. Hepatitis $\mathrm{B}$ virus transactivator MHBst: activation of NF-KB, selective inhibition by anti- 
oxidants and integral membrane localization. EMBO J 1992;11:2991-3001

Napoli C, Ignarro LJ. Nitric oxide and atherosclerosis. Nitric Oxide 2001;5:88-97

Neuzil J, Weber C, Kontush A. The role of vitamin E in atherogenesis: linking the chemical, biological and clinical aspects of the disease. Atherosclerosis 2001;157:257-83

Palozza P, Serini S, Torsello A, Di Nicuolo F, Piccioni E, Ubaldi V, Pioli C, Wolf FI, Calviello $\mathrm{G}$. $\beta$-carotene regulates NF-kappaB DNA-binding activity by a redox mechanism in human leukemia and colon adenocarcinoma cells. J Nutr 2003;133:381-8

Pierce GF. Macrophages: important physiologic and pathologic sources of polypeptide growth factors. Am J Respir Cell Mol Biol 1990;2:233-4

Rhodus NL, Cheng B, Myers S, Bowles W, Ho V, Ondrey F. A comparison of the pro-inflammatory, NF- $\kappa B$-dependent cytokines: TNF- $\alpha, \mathrm{IL}-1 \alpha, \mathrm{IL}-6$, and IL- 8 in different oral fluids from oral lichen planus patients. Clin Immunol 2005;114: 278-83

Ritchlin CT, Haas-Smith SA, Li P, Hicks DG., Schwarz EM. Mechanisms of TNF- $\alpha$ - and RANKL-mediated osteoclastogenesis and bone resorption in psoriatic arthritis. J Clin Invest 2003;111:821-31

Schreck R, Meier B, Mannel DN, Droge W, Baeuerle PA. Dithiocarbamates as potent inhibitors of nuclear factor $\kappa B$ activation in intact cells. J Exp Med 1992;175:1181-94

Simons RK, Junger WG, Loomis WH, Hoyt DB. Acute lung injury in endotoxemic rats is associated with sustained circulating IL-6 levels and intrapulmonary CINC activity and neutrophil recruitment--role of circulating TNF- $\alpha$ and IL- $\beta$ ? Shock 1996;6:39-45

Smith TA. Carotenoids and cancer: prevention and potential therapy. Br J Biomed Sci 1998;55:268-75
Storz P, Toker A. Protein kinase D mediates a stress-induced $\mathrm{NF}-\kappa \mathrm{B}$ activation and survival pathway. EMBO J 2003; 22:109-20

Szabo C, Southan GJ, Thiemermann C. Beneficial effects and improved survival in rodent models of septic shock with S-methylisothiourea sulfate, a potent and selective inhibitor of inducible nitric oxide synthase. Proc Natl Acad Sci USA 1994; $91: 12472-6$

Tak PP, Gerlag DM, Aupperle KR, van de Geest DA, Overbeek M, Bennett BL, Boyle DL, Manning AM, Firestein GS. Inhibitor of nuclear factor $\kappa B$ kinase beta is a key regulator of synovial inflammation. Arthritis Rheum 2001; 44:1897-907

Thornberry NA, Bull HG, Calaycay JR, Chapman KT, Howard AD, Kostura MJ, Miller DK, Molineaux SM, Weidner $\mathrm{JR}$, Aunins J. A novel heterodimeric cysteine protease is required for interleukin-1 $\beta$ processing in monocytes. Nature 1992;356: 768-74

Traenckner EB, Pahl HL, Henkel T, Schmidt KN, Wilk S, Baeuerle PA. Phosphorylation of human IאB- $\alpha$ on serines 32 and 36 controls $1 \kappa \mathrm{B}-\alpha$ proteolysis and NF- $\kappa \mathrm{B}$ activation in response to diverse stimuli. EMBO J 1995;14:2876-83

van der Saag PT, Caldenhoven E, van de Stolpe A. Molecular mechanisms of steroid action: a novel type of cross-talk between glucocorticoids and NF- $\mathrm{kB}$ transcription factors. Eur Respir J Suppl 1996;22:146s-53s

Vivekananthan DP, Penn MS, Sapp SK, Hsu A, Topol EJ. Use of antioxidant vitamins for the prevention of cardiovascular disease: meta-analysis of randomised trials. Lancet 2003;361:2017-23

Witschi $\mathrm{H}$. Carcinogenic activity of cigarette smoke gas phase and its modulation by $\beta$-carotene and $\mathrm{N}$-acetylcysteine. Toxicol Sci 2005;84:81-7

Xie QW, Kashiwabara Y, Nathan C. Role of transcription factor NF- $\mathrm{KB} / \mathrm{Rel}$ in induction of nitric oxide synthase. J Biol Chem 1994;269:4705-8 